\title{
Skill Trends Under Capitalism and the Socialisation of Production
}

\author{
Paul S. Adler \\ in C. Warhust, I. Grugulis, and W. Keep, eds, The Skills That Matter, Houndmills: Macmillan \\ Palgrave, 2004, pp. 242-260.
}

Defining and understanding skill is, as several contributors to this volume have shown, a difficult task - and empirical data often do not resolve the problem. Very complex practices are often categorised as unskilled because the groups performing them are low status (Bolton in this volume). Conversely, collective action can result in job designs that call for more skill and force management to upgrade categorisations for existing jobs (Turner 1962). Analysis is further complicated when the focus is broadened to the host of economic, institutional, and political factors involved in shaping work and defining skill (as discussed in this volume, especially by Clark and Hermann; Darr; Rainbird et al.; Lloyd and Payne).

When confronted with such a puzzling set of problems, a return to theory is often useful. This chapter returns to the roots of one of the most prominent theories of skill, Labour Process Theory (LPT) (see Thompson 1989; Wardell et al. 1999; Grugulis et al. 2001). Much of LPT has sought its grounding in Marxist theory, although Marxist ideas have become less central to LPT in recent years. This chapter argues that LPT has frequently been one-sided in its reading of Marx, and that this one-sidedness has hobbled our ability to understand trends in skill. In turn, this handicap has encouraged scholars to abandon Marxist ideas (although this is far from the only factor behind that shift). This chapter proposes an alternative reading of Marx, one that helps generate a better understanding of the nature of skill and the changes in skill associated with the development of capitalism.

\section{Confronting Upgrading}

From its inception, LPT has been critical of those writers who claim to see upgrading trends in skill (for example Bell 1973) and the emergence of 'new paradigms' in work organisation (for example Piore and Sabel 1984; Kern and Schumann 1984; Mathews 1994). The first wave of LPT adopted what can be termed a 'neo-Marxist' viewpoint. At first, it was argued that capitalist imperatives of profit and control led inexorably to deskilling. Numerous studies compellingly described cases of deskilling in various occupations. Over the years, and confronted with conflicting examples and arguments, its proponents have nuanced their positions, and neo-Marxist LPT now entertains three main alternatives: deskilling, polarisation, and a contingency view.

One reason for the loss of the centrality of Marxist ideas in LPT is that, due to the specific form of Marxist theory that has been invoked, it is inconceivable that over the 
longer term and in the aggregate, the skills of the workforce could have trended upward. Yet not only are upgrading counter-examples common in the literature, but the overall path of development of capitalism in the last century is arguably one of upgrading.

Consider, first, the evolution of the occupational distribution of the workforce. Table 1 shows data on the case of the US over the twentieth century. There are, of course, many difficulties in interpreting these data, not least of which is what is meant by skill - a point taken up again below. But whatever we mean by skill, it is difficult not to see in this mutation of the occupational structure an important upgrading, notably in the massive contraction of the unskilled farm and non-farm labourer category, the more recent contraction of the operative category, and the growth of the professional and technical category. (It should be noted too that many people classified in the growing category of managers and administrators have very little managerial authority and arguably belong to the working-class broadly construed.) Buchanan et al. in this volume offer similar data for Australia, suggesting that it has been a broad development.

Table 1: Evolution of the US occupational structure

\begin{tabular}{|l|c|c|c|}
\hline Year & $\mathbf{1 9 0 0}$ & $\mathbf{1 9 7 0}$ & $\mathbf{2 0 0 0}$ \\
\hline Clerical & $\mathbf{0 . 0 3}$ & $\mathbf{0 . 1 8}$ & $\mathbf{0 . 1 6}$ \\
\hline Professional, technical & $\mathbf{0 . 0 4}$ & $\mathbf{0 . 1 4}$ & $\mathbf{0 . 1 6}$ \\
\hline $\begin{array}{l}\text { Service workers, excluding private } \\
\text { household }\end{array}$ & 0.04 & 0.11 & \\
\hline Private household workers & 0.05 & 0.02 & \\
\hline $\begin{array}{l}\text { Total service, including private } \\
\text { household }\end{array}$ & $\mathbf{0 . 1 0}$ & $\mathbf{0 . 1 3}$ & $\mathbf{0 . 1 4}$ \\
\hline Salesworkers & $\mathbf{0 . 0 5}$ & $\mathbf{0 . 0 7}$ & $\mathbf{0 . 1 2}$ \\
\hline Operative and kindred and & 0.13 & 0.18 & \\
\hline $\begin{array}{l}\text { Labourers, excluding farm } \\
\text { mine }\end{array}$ & 0.13 & 0.05 & \\
\hline $\begin{array}{l}\text { Total operatives plus labourers } \\
\text { (excluding farm) }\end{array}$ & $\mathbf{0 . 2 6}$ & $\mathbf{0 . 2 3}$ & $\mathbf{0 . 1 2}$ \\
\hline $\begin{array}{l}\text { Managers, } \\
\text { proprietors }\end{array}$ & $\mathbf{0 . 0 6}$ & $\mathbf{0 . 0 8}$ & $\mathbf{0 . 1 1}$ \\
\hline Craftsmen, foremen & $\mathbf{0 . 1 1}$ & $\mathbf{0 . 1 4}$ & $\mathbf{0 . 1 2}$ \\
\hline Farmers & 0.20 & 0.02 & \\
\hline Farm labourers and foremen & 0.18 & 0.01 & \\
\hline $\begin{array}{l}\text { Total farmers plus farm } \\
\text { labourers }\end{array}$ & $\mathbf{0 . 3 8}$ & $\mathbf{0 . 0 3}$ & $\mathbf{0 . 0 4}$ \\
\hline
\end{tabular}


Source: Data for 1900 and 1970 from US Bureau of the Census (1975). Data for 2000 are author's imputation from US Bureau of Census (2000). Census data after 1970 combine operatives and labourers, do not distinguish private household workers and do not distinguish farm labourers from farmers and farm managers.

How do Marxist-inspired labour process theorists respond to this kind of data? Braverman (1974) anticipated the most common responses. He recommends we ignore such occupational data, because, firstly, they do not recognise the many experience-based skills of farmers and farm labourers; secondly, by classifying manufacturing operatives as semi-skilled just because they work with machinery, they inflate these skills compared to those of labourers, classified as unskilled; thirdly, they ignore the class difference between middle-class professional/technical categories and the working-class narrowly construed; and fourthly, they ignore the dilution over time of skills in the craft category. While there is some truth to all these objections, it nevertheless takes a huge effort of imagination to see the shift registered in these statistics as compatible with an aggregate deskilling story. And where scholars have been able to use independent measures of skill such as the Dictionary of Occupations, none has found evidence of aggregate deskilling or meaningful polarisation: a modest upgrading trend is the almost universal conclusion (see the comprehensive review of US studies by Spenner (1988); for more recent UK data, see Felstead et al. this volume. 'Meaningful polarisation' refers to the possibility discussed by Braverman (1974: 425) that a sizeable minority of the work force experience deskilling while others, and perhaps the overall average, experienced upgrading.)

Second, consider the average education level of the workforce - arguably an important indicator of skill: it, too, has increased dramatically. The fraction of US 17 year-olds who had completed high school grew from six per cent in 1900, to 57 per cent in 1950, to over 80 per cent by the end of the century. Braverman (1974) suggests ignoring this evidence too, since, firstly, it reflects the demands of urbanisation rather than industry; secondly, it is biased by the inclusion of non-working class categories; thirdly, school is a way to keep unemployed youth off the streets; and, fourthly, many workers' education is underutilised in the workplace. Again, these points all have some validity. However, despite this huge increase in the supply of more-educated labour, high school and college education has continued to yield a sizable positive economic return in the labour market (Goldin and Katz 1999) and this result is difficult to understand unless at least some of this increase in education levels reflected increasing skill requirements rather than pure screening and credentialism (Abramowitz and David 1996). As Goldin and Katz write, the most plausible explanation for this pattern is that 'technological change and capital deepening have both served to increase the demand for more-skilled labour over the long run' (1999: 25-26). A considerable body of economic research has consistently found that capital equipment and worker skills are complements rather than substitutes.

Faced with evidence such as this, it is not surprising that LPT has shifted away from broad trend generalisations towards a contingency view: 
LPT is not dependent on deskilling or Taylorism as the characteristic form of the capitalist labour process. Its core theory merely recognises that competitive relations compel capital to constantly revolutionise the labour process and that within that framework, capital and labour will contest the character and consequences of such changes. (Smith and Thompson 1999: 211).

Compared to the deskilling argument, such a contingency view is easier to reconcile with the murky data - but it is harder to reconcile with LPT's ostensible Marxist grounding. It is one thing to argue that workers sometimes succeed in forcing management to upgrade jobs and in forcing government to provide greater access to education. But the idea that the balance of class power should be so favorable to workers over such large aggregates and over such a long period is difficult to reconcile with any theory that characterises contemporary society as capitalist. If the data do show a long-term, aggregate upgrading trend, surely the more basic driving factor must be industry's needs for skilled labour.

To date, those who have seen an upgrading trend have usually distanced themselves from Marx. Moreover, many have simply ignored the large mass of relatively low-skilled workers that still anchors the bottom of the occupational skill distribution. They write about the long-term trends they claim to discern as if this mass were about to disappear overnight. Many recent champions of the 'knowledge society,' for example, write as if we will all shortly be 'symbolic analysts' (Reich 1993) while, in reality, low-skilled, routine jobs continue to proliferate (Warhurst and Nickson 2001).

Thus on the one side there is a utopianism that ends up masking a scandal, and on the other a polemical denunciation that seems unable to acknowledge some basic facts. There is, however, a version of Marx - one that can be termed 'paleo-Marxist' - that is easy to reconcile with both a broad pattern of upgrading and a multitude of counter-examples of deskilling. (I call this view paleo because it was common prior to World War I but was subsequently eclipsed by neo-Marxism.) This chapter attempts to explicate that paleo point of view, arguing that capitalism progressively upgrades skills as part of the process Marx called the socialisation of the forces of production.

My thesis is that this paleo-Marxist view provides us a powerful conceptual tool for analysing skill and its evolution (see also Hirschhorn 1984; Kenney and Florida 1993; Engeström 1987 \& 1990). The form of argument used in this chapter is assertion rather than demonstration. I would beg readers' indulgence and ask them to try to see the skill problem through these paleo lenses, in the hope that this effort will be rewarded by a richer understanding of skill.

\section{Two Components of Skill}

Skill, it is widely acknowledged, has two basic components: mastery of the complexity of the tasks required of workers in their jobs, and mastery of the relations that coordinate 
activity across these tasks. (Littler, 1982, identifies a third component, the social construction of skill, which can be treated as a super-structural overlay over the two basic components.) There is broad agreement that task complexity can be measured (in principle) by the amount of required education and training. But the measurement of the relational component is more difficult. Many argue that the key aspect of work relations is the autonomy and discretion they afford. The premise of my argument is that autonomy/discretion is precisely the wrong yardstick. As others have pointed out, it is entirely backward-looking, reflecting nostalgic regret for the passing of the autonomous craftsman (or alternatively, reflecting the ideal of alienated, self-sufficient individualism that is the spontaneous ideology of market society). This yardstick allows a measurement of what has often been lost in the development of the capitalism; but there is also a need to have a way to understand what has replaced that lost autonomy.

Autonomy is merely the converse of interdependence, and to understand the changing nature of work-relations and of skill more generally, we need to understand the changing forms of interdependence. Much work in LPT, starting with Braverman, has implicitly assumed that this interdependence can, under capitalist conditions, only be one of coercive dependence. If that were the case, then loss of autonomy might indeed be a useful yardstick. In reality, however, interdependence can take either coercive or collaborative forms, and therefore a useful theory of skill must help to understand these forms and the relations between them.

I submit that Marx's theory of the socialisation of production provides a strong theoretical foundation for this task. But in order to make this argument, the paleo reading of Marx needs first to be explained.

\section{Reading Marx}

Scholars working in the Marxist tradition all accept as their point the proposition that: 'the development of the contradictions of a given historical form of production is the only historical way in which it can be dissolved and then reconstructed on a new basis' (Marx 1977: 619). However, Neo- and paleo-Marxists offer conflicting interpretations of 'developing contradictions.'

For neo-Marxists, class struggle is the motor of history and the development of the contradictions of capitalism consists of intensified worker struggles in reaction to exacerbated exploitation and misery. For paleo-Marxists, by contrast, the basic contradiction is between the forces and the relations of production. (The forces of production are composed of instruments, raw materials, workers' productive faculties, and organising principles; the relations of production are the relations of control over the productive forces.) Under capitalism, the progressive socialisation of the forces of production comes into escalating conflict with the persistence of relations of production based on private property. In the paleo view, the long-term path of development of the class struggle is determined by the evolution of the underlying contradiction between 
forces and relations of production. (This reading is based on G.A. Cohen's (1978) exposition of Marx's theory of history. This chapter takes Cohen's interpretation from the general societal plane into the production process.)

Socialisation plays a pivotal role in this paleo reading of Marx's analysis of the dynamics of capitalist development. Socialisation is commonly construed as the process whereby people new to a culture internalise its norms: Marx's use is broader. Marx's (1973) discussion of the socialisation of the forces of production (as distinct from his arguments in favour of the socialisation of property relations) suggests that this psychological internalisation is just one form of a more general phenomenon: elements of the labour process are socialised insofar as they come to embody the capabilities and constraints developed in the larger society rather than only those that emerge from the isolated, private experience of local contexts. The 'objective' socialisation of the forces of production is thus visible in the complexification of the social division of labour - the specialisation of industries and regions, and their increasing global interdependence (see also van der Pijl 1998; Sohn-Rethel 1978; Engels 1959).

To these 'objective' dimensions of socialisation corresponds a subjective dimension. The civilising mission of capitalism is not only to stimulate enormously the quantitative development and qualitative interdependence of the objective components of the forces of production but also, and more fundamentally, to take a decisive step in the realisation of humankind's social nature -- in our socialisation As the objective features of these relations are transformed, so too are the subjective ones:

The bourgeoisie, historically, has played a most revolutionary part. The bourgeoisie, wherever it has got the upper hand, has put an end to all feudal, patriarchal, idyllic relations ... In place of the old local and national seclusion and self-sufficiency, we have intercourse in every direction, universal interdependence .... And as in material, so in intellectual production. The intellectual creations of individual nations become common property. National one-sidedness and narrow-mindedness become more and more impossible ... The bourgeoisie ... has rescued a considerable part of the population from the idiocy of rural life ... [W]ith the development of industry, the proletariat not only increases in numbers; it becomes more concentrated in greater masses, its strength grows, and it feels that strength more ... The union is helped on by the improved means of communication that are created by modern industry and that place the workers of different localities in contact with one another ... The advance of industry, whose involuntary promoter is the bourgeoisie, replaces the isolation of labourers, due to competition, by their revolutionary combination, due to association ... What the bourgeoisie, therefore, produces, above all, is its gravediggers. (Marx and Engels 1959: 9-20)

The development of the forces of production pulls workers out of what Marx and Engels call 'rural idiocy'. In the Poverty of Philosophy, Marx (1884) similarly celebrates the end 
of 'craft idiocy'. Here the term idiocy preserves both its colloquial sense and the meaning from the Greek idiotes, denoting an asocial individual isolated from the polis.

Under capitalism, this socialisation tendency is simultaneously stimulated, retarded and distorted by the prevailing relations of production. Competitive pressures force firms to break down parochialisms and to stimulate technological progress; but the 'universal interdependence' thus created appears, in the first instance, only behind the twin veils of commodity fetishism and bureaucratic employment relations. Instead of a broadening association of producers progressively mastering their collective future, capitalism imposes the coercion of 'laws' of the market and of corporate bureaucracy. Whence capitalism's inability to manage public goods and externalities, issues whose importance grows with the increasing complexity of technology and knowledge-intensity of the economy. As a result, the path of socialisation, both objective and subjective, is halting and uneven. It should be noted too that even progressive change has social costs: far too many workers bear the burdens of structural unemployment; old union craftsmen are pitted against young nonunion technicians; contracting-out and globalisation undermine old solidarities.

However, in the overall dynamics of capitalism, these various 'counter-tendencies' must and do cede to the overall progress of socialisation. In modern industry, competitive advantage often flows from skill upgrading and greater collaborative interdependence within and between firms, and the pursuit of those sources of competitive advantage makes capitalists the 'involuntary promoters' of socialisation.

In analysing the evolution of skill and work organisation, LPT has too often truncated this dialectic. Marx writes:

If capitalist direction [of work] is thus twofold in content, owing to the twofold nature of the process of production which has to be directed - on the one hand a social labour process for the creation of a product, and on the other hand capital's process of valorisation - in form it is purely despotic. (Marx 1977: 450)

Neo-Marxist LPT interprets this passage to mean that the historical development of capitalist work organisation reflects above all the balance of class forces - despotism versus resistance. Paleo-Marxists, by contrast, recall that in Marx's Hegelian discourse, content and form can be in contradiction with each other (the paradigmatic case for Marx being that of the contradiction between use-value and exchange-value of the commodity). The paleo reading of this passage thus highlights the growing contradiction between an increasingly socialised labour process (the content) and the barriers posed to further socialisation by the persistence of valorisation constraints (the form). Three short cases help illustrate this point. 


\section{Case1 : Taylorism and scientific management}

Taylorism and the broader scientific management movement to which it was central are depicted in much LPT as an offensive in the class struggle. The paleo view acknowledges this reality, but identifies a second aspect as more fundamental: Taylorism was also a progressive step in the socialisation of the forces of production, both objective and subjective (Sohn-Rethel 1978). Indices of socialisation include the following:

- Under scientific management, planning replaces anarchy in enterprises of growing scale: the planning department helps assure an efficient flow of materials through more-tightly interdependent operations.

- The determination of work methods and standards is no longer only a function of isolated, local struggles between workers and their bosses - it is informed by a body of socialised knowledge, Taylor's 'science' of work. In reality, this science took the form of a largely inductive and empirical 'engineering,' often subject to management bias; but even in this form, the 'mysteries' of work are dissolved and knowledge of the labour process is socialised. Workers can and often do refer to this knowledge to buttress their claims in negociations with management.

- The 'collective worker' is broadened by the development of a more differentiated and integrated division of labour. A specialised planning staff is formed, as are numerous types of 'functional foreman'. The functional foremen roles advocated by Taylor were subsequently transformed into distinct support and staff functions, expanding technical occupations that are also part of the working-class broadly construed.

- The object of work expands in a socialised direction, so that individual workers' tasks expand from assuring production at their own workstations to include more deliberate coordination with others and more planned performance-improvement efforts. When mobilised in these tasks, workers find their horizons broadened.

Neo-Marxist LPT theory is correct to insist that this all happens under capitalist authority. The resulting socialisation is therefore one-sided and distorted. But it is no less real. On the one hand, Taylorism had profoundly revolutionary effects on the management of large-scale production, with important positive effects for workers: higher productivity facilitating higher wages, fewer accidents, more promotion opportunities into technical occupations, a drastic reduction in the exercise of arbitrary personal authority in the 'foreman's empire', the experience of disciplined collective work on a large scale, and the opportunity to broaden trade union structures from narrow crafts to whole industries. On the other hand, capitalist use and abuse of Taylorism sometimes undermined or distorted these gains by turning Taylorism against workers with a loss of autonomy to remote planning departments, some job losses, the creation of some very repetitive, shortcycle jobs and a disruption of traditional craft bases of working-class resistance. Taylorism may well have been negative for craft workers; but just as plausibly it constituted a net improvement for the far greater mass of less skilled labourers and 
operatives. The overall effects on workers were mixed; but on balance socialisation advanced.

The paleo view can call several witnesses for this more dialectical reading of Taylorism. In the US, the Amalgamated Clothing Workers under Sidney Hillman encouraged the adoption of scientific management techniques, even conducting seminars for workshop owners, in order to rationalise production and pay (Fraser 1991). Progressive Taylorites such as Morris L. Cooke broadened the scope of scientific management to city and national economic planning (see Nyland 1998; Schachter 1989). In Sweden, trade unions in the metal trades and the textile industries gained considerable influence over wages and conditions as a result of the (management-driven) introduction of time-and-motion studies (De Geer 1982).

\section{Case 2: Lean production}

Lean production takes Taylorism to new heights. Its effects are still under debate: many critics argue that it represents an intensification of work and of managerial control (Babson 1995). But one aspect of lean production that has not received enough attention is its contributions to the socialisation of production.

This argument can be illustrated with excerpts from interviews that I conducted with workers at NUMMI. NUMMI is a unionised auto assembly plant in Northern California, jointly owned by GM and Toyota, but operating under Toyota's day-to-day control. The plant inherited its facility and almost its entire workforce (but none of it managers) from the old GM-Fremont organisation in 1983. It quickly reached 'world-class' levels of productivity and quality, relying on a rigorous implementation of the Toyota Production System, in particular, its 'standardised work' policy (Adler 1993). Standardised work is a process for determining the 'one best way' to perform a job but whereas under traditional Taylorism this determination was made by a specialist, here workers themselves hold the stop-watch and analyse alternative methods. Reflecting the added complexity of workers' tasks, new hires at NUMMI receive more than 250 hours of training during their first six months on the job, while a typical new hire in the Big Three receives 42 hours.

Interviews revealed a number of dimensions in which socialisation seemed to be at work at NUMMI. Quoting several union production workers comparing NUMMI and GMFremont:

- Collective rationality tends to supercede power relations: 'The GM system relied on authority. People with rank - the managers - ruled regardless of their competence or the validity of what they were saying. It was basically a military hierarchy. At NUMMI, rank doesn't mean a damn thing — standardised work means that we all work out the objectively best way to do the job, and everyone does it that way. I might make some minor adjustments because of my height, for example, but I follow the procedure we've laid out because it makes sense.' 
- Task knowledge is socialised: "The great thing about standardised work is that if everyone is doing the job the same way, and we run into a problem, say a quality problem, we can easily identify where its coming from and fix it. If everyone is doing the job however they feel like, you can't even begin any serious problemsolving.'

- The collective worker is broadened to the plant: 'The work teams at NUMMI aren't like the autonomous teams you read about in other plants. Here, we're not autonomous because we're all tied together really tightly. But it's not like we're just getting squeezed to work harder, because it's us, the workers, that are making the whole thing work - we're the ones that make the standardised work and the kaizen suggestions. We run the plant - and if it's not running right, we stop it.'

- The collective worker is broadened to include supplier firms: 'In 23 years working for GM, I never met with a supplier. I never even knew their names except for the names on the boxes. Now, we're working with suppliers to improve our products. Workers sit down with our engineers and managers and the suppliers' people and we analyse defects and develop improvement proposals. We even do that with equipment vendors. Stuff like that really gives us a better perspective on how our jobs relate to the whole process. We're not just drilling holes and slamming nuts onto bolts anymore. Now we have a say in how the product should be made.'

- Collaborative interdependence becomes a norm beyond work: 'I wish you could talk to the guys' wives about the changes they've seen. I was a typical macho horse's ass when I worked at Fremont. When I got home, I'd get a beer, put my feet up and wait for dinner to be served. I'd figure, 'I've done my eight, so just leave me alone.' Now, I'm part of a team at work, and I take that attitude home with me, rather than dump my work frustrations all over my family. I'm much more of a partner around the house. I help wash the dishes and do the shopping and stuff. My job here is to care, and I spend eight hours a day doing that job, so it's kind of natural that I take it home with me.'

Counter-posed to these features of work organisation at NUMMI was an array of forces reflecting valorisation pressures that limited socialisation. Under profitability performance pressure, management has sometimes sacrificed worker health and safety for profits. Management has never whole-heartedly accepted the union as a legitimate expression of workers' voice (Adler et al. 1997 \& 1998). Competitive relations within the organisation and between it and other parts of its institutional field have often undermined collaboration. However, analysis of work organisation must register too the profoundly positive effects for workers that flow from the socialisation wrought by lean production at NUMMI.

Case 3: Software development 
As software has grown more complex over the past few decades, the software development process has slid into chaos. One 1994 survey of 8,330 projects in 365 firms in banking, manufacturing, retail, wholesale, healthcare, insurance, and government (Standish Group 1994) found that:

- only 16 per cent of projects were on time, within budget and met originally specified requirements - only nine per cent in large companies;

- 31 per cent of projects were 'impaired' and eventually cancelled;

- 53 per cent of projects were 'challenged' and the average challenged project met only 61 per cent of its requirements; and

- the average impaired or challenged project was 189 per cent over budget and 222 per cent over schedule.

It is therefore not surprising that over this same period, the software field has been the object of numerous 'rationalisation' efforts. Examples include structured programming, project planning models, information engineering, and object-oriented programming. Currently, one of the most influential efforts is based on the 'Capability Maturity Model' (CMM) (see Software Engineering Institute 2002).

The CMM owes its birth to the US Department of Defense's increasing frustration with the chaos in software development. The Department of Defense (DoD) funded the Software Engineering Institute (SEI), based at Carnegie-Mellon University, to develop a model of a more reliable development process. With the assistance of the MITRE Corporation and input from nearly 1000 industry people, SEI released the CMM in 1991. The model distinguishes five successively more 'mature' levels of process capability, each characterised by mastery of a number of Key Process Areas (KPAs). Level 1 represents an entirely ad hoc approach. Level 2 represents the rationalisation of the management of individual projects. Level 3 characterises the systematic management of its portfolio of projects. Level 4 addresses the quantification of the development process. Level 5 addresses the continuous improvement of that process. The underlying philosophy of this hierarchy was inspired by Crosby's (1979) TQM approach to quality in manufacturing (Humphrey 2002).

The CMM has become the basis for numerous software service organisations' improvement efforts in both the government and commercial sectors. Its diffusion has been driven in considerable measure by its use in sourcing decisions by the DoD and other government and commercial-sector organisations. The first sourcing evaluations pressed suppliers to reach Level 2 but by the late 1990s the bar had been raised to Level 3.

Accumulating evidence suggests that moving up the CMM hierarchy leads to improvements in product cost, quality and timeliness (Clark 1999; Harter et al. 2000; Krishnan et al. 2000; Herbsleb et al. 1997). But many sceptics remain unconvinced. These gains may be specific to the sampled organisations. They may be earned at the 
expense of developer morale and commitment, and given the importance of developers' attitudes to performance, any performance gains may therefore be ephemeral. Typical of opposition to standardised and formalised methodologies is this assessment by two wellrespected software management experts:

Of course, if your people aren't smart enough to think their way through their work, the work will fail. No Methodology will help. Worse still, Methodologies can do grievous damage to efforts in which people are fully competent. They do this by trying to force the work into a fixed mold that guarantees a morass of paperwork, a paucity of methods, an absence of responsibility, and a general loss of motivation. (DeMarco and Lister 1987: 116)

One software development manager interviewed in my research expressed the concern this way: 'Programming has always been seen as more of an art form than a factory process. Programmers are supposed to be creative, free spirits, able to figure things out themselves. So the software factory idea was very alien to the culture of programmers.'

Most LPT research on these kinds of efforts to rationalise software development has reflected a similarly deep scepticism (Kraft 1977; Greenbaum 1979; Friedman and Cornford 1989). Kraft (1977: 61) summarizes the analysis this way:

'Canned programs, structured programming, and modularization are designed to make the supervision of software workers by managers easier and more like the supervision of other workers...Such managerial techniques have made possible the use of relatively less skilled programmers for what were formerly the most complex software tasks.' More recent LPT research has nuanced this analysis, more consistent with a contingency version of LPT (Greenbaum 1998; Beirne et al. 1998).

To explore the impact of rationalised systems such as the CMM on developers, I studied a large software consulting firm, conducting interviews with developers and managers in four units (see Adler 2003). These units all developed and maintained relatively largescale systems for government clients. Two were at CMM Level 5 and two sister units were at Level 3. Interviews revealed several indices of socialisation:

- Expanding the object of work: "At Level 5, you understand what other people are doing and why. Everyone can discuss and are involved in improvement efforts, not only technical but also process, organisational problems - versus at Level 1, where the only improvements people that can talk about are local and technical. And at Level 5, measurement is a part of life. At worst, people tolerate it. The majority see it as an integral part of their work - versus at Level 1, where measurement is not part of the culture, where it's not seen as having value, and where it's seen as waste, bureaucratic overhead, and people feel "Just leave me alone.".'

- Broadening the collective worker: 'Before, I used to just go do the job. Here it's more of a team effort. There are more people working on development, so we 
need to coordinate with each other more closely. And we need to coordinate more closely with other groups, like QA.'

- Deepening collaborative interdependence: 'In a small organisation doing small projects, you have a lot of flexibility, but there's not much sharing. You're kind of on your own. Here, I'm just a small part of a bigger project team. So you don't do anything on your own. It's a collaborative effort.'

- Socialising the tools used in work: 'Developers want above all to deliver a great product, and the process helps us do that. What I've learned coming here is the value of a well thought-out process, rigorously implemented, and continuously improved. It will really improve the quality of the product. In this business, you've got to be exact, and the process ensures that we are. You have to get out of hacker mode!'

- Socialising the development of rules and tools: "People have to be a part of defining the process. We always say that "People support what they help create." That's why the Tailoring Cycle [for defining the procedures to be used in the management of each specific project] is so important. As a project manager, you're too far away from the technical work to define the [procedures] yourself, so you have to involve the experts. You don't need everyone involved, but you do need your key people. It's only by involving them that you can be confident you have good [procedures] that have credibility in the eyes of their peers.'

- Socialising skill-formation processes: 'We had an informal training and mentoring program, and when we got serious about the CMM, we wrote it down. Writing the process down has had some great benefits. It's made us think about how we work, and that's led to improvements. For example, formalising the training program has helped bring some outliers into conformance.'

There were also counter-tendencies too. The socialisation of the software development process under CMM was simultaneously stimulated, retarded and distorted by the valorisation process. On the one hand, valorisation pressures were expressed in the pressure from large customers for product quality, cost, and timeliness and in customer pressure too to adopt the CMM as a gauge of the organisation's commitment to those goals. On the other hand, valorisation pressures also had negative effects, creating:

- Narrow, short-term profit goals that impeded investment in automation, simplification and support that would have had beneficial long-term effects:

One key challenge [in maintaining the use of CMM as a tool for process improvement] is maintaining buy-in at the top. Our top corporate management is under constant pressure from the stock market. The market is constantly looking at margins [...] That doesn't leave much room for expenditures associated with process improvement - especially when these take two or three years to show any payoff. 
- Centrifugal effects of distinct performance pressures on customers and suppliers: While process maturity encouraged more collaborative relations with clients for requirements definition and progress review, performance pressures often pulled the parties apart and limited this collaboration.

- Tension between corporate interests and the collective interests of its employees: While rules defining the development process often appeared to workers as enabling rather than coercive, some managers used these formal procedures as weapon against employees.

- Tension between the collective nature of work and the individualising effects of the wage relation: As vulnerable employees dependent on wage income, and reflecting their prior socialisation, developers sometimes resisted the new forms of interdependence associated with CMM Levels. While most developers appeared to embrace the interdependence demanded by high CMM levels, some were concerned that CMM-style rationalisation made the development process less 'people-dependent' and that their job security might suffer.

In aggregate, the effects of valorisation were weaker than those of socialisation, but the former were strong enough to make progress halting and uneven. In the words of one interviewee:

We still have to deal with the 'free spirits' who don't believe in process. These are typically people who have worked mainly in small teams. It's true that a small group working by itself doesn't need all this process. But we rarely work in truly independent small teams: almost all our work has to be integrated into larger systems, and will have to be maintained by people who didn't write the code themselves. These free spirits, though, are probably only between two per cent and four per cent of our staff. We find some of them in our advanced technology groups. We have some in the core of our business too, because they are real gurus in some complex technical area and we can't afford to lose them. And there are some among the new kids coming in too: many of them need convincing on this score. Most of them adapt, although some don't and they leave.

\section{Socialisation and Skill}

These sketches of the socialisation of the labour process under Taylorism, lean production, and the CMM suggest a need to broaden our conceptual horizon in understanding skill. Skill matters not only in relation to its level but also in its form. Relative to complexity, training requirements often increased but also, and perhaps more fundamentally, this training has changed in form from apprenticeship to formal technical and scientific education. Similarly, work relations have changed, not only requiring more interactive, social skills, but also broadening their scope. Braverman was correct to highlightthe fundamental difference between the autonomous collaboration of peers in a craft workshop and the formalized co-ordination work in modern bureaucracies. But 
Marx's notion of socialisation signals the enormous postitive significance of this shift in the form of training, knowledge, and coordination - a shift towards forms that embody 'universal interdependence' rather than rural and craft 'idiocy'.

Whereas neo-Marxist LPT focuses exclusively on the noxious effects of capitalist relationsof production, the paleo view advanced sees skill as being at the intersection of the forces and the relations of production, and influenced by both. Using this paleo framing, the broader research findings on the long-term, aggregate evolution can be synthesized under two headings:

- The impact of the progressive development of the forces of production: The impact on task complexity is seen in tendencies to upgrading discussed in the opening pages of this chapter. The impact on work relations is seen in a progressive differentiation of roles and increasing collaborative interdependence at various levels: between workers (team work), work teams (process management), hierarchical levels (employee involvement), specialised functions (cross-functional teams), and firms (supplier partnerships). Whence the growing importance of interactive, social, and emotional skills discussed in other chapters of this volume. It is true that the autonomy and nobility of traditional crafts are trampled underfoot in this process, but the larger mass of workers often find the complexity of their tasks increased and their work relations broadened. Increasing proportions of men and women are drawn into mixed-gender, interdependent work relations. Workers are also drawn from local isolation into the web of globalisation, which also tends to increase complexity and broaden relations in developing countries (Warren 1980).

- The impact of the maintenance of capitalist relations of production: The impact of the relations of production, too, can be seen in both the task complexity and work relations dimensions of skill. Competitive pressures force firms sometimes to sacrifice long-term for short-term gains, and always to privilege firm over social benefits. Tentative moves towards inter-firm collaboration are constantly undermined by competitive rivalry. The wage relation privileges owners' interests over those of workers'. As owners' agents, managers sometimes find it profitable, if only in the short-term, to deskill work, manipulate teamwork to create peer pressure, let horizontal specialisation degenerate into adversarial rivalry, and use hierarchy for 'command and control'. These effects should not be ignored as mere 'noise' in the data: they reflect the deep structure of property relations under capitalism. It is therefore appropriate that critical scholars should highlight and denounce them as reflecting an important, imminent tendency of capitalism.

What can be said about the relationship between these two sets of forces in the overall evolution of skill and capitalism? The neo-Marxist interpretation that has been dominant in LPT gives little causal efficacy to the forces of production and argues that capitalist development, shaped primary by the class struggle inherent in capitalist relations of production, leads tendentially to increasing misery, including the deskilling and degradation of work. On the paleo view, the development of capitalism is profoundly 
shaped by the progressive socialisation of the forces of production. Over the long run, the overall effect is to create a working-class that is increasingly educated, sophisticated, accustomed to the discipline of large-scale collective endeavour - and thus increasingly capable of successfully taking on the task of radically transforming society. (This thesis, please note, concerns capabilitiy: Whether workers are motivated to undertake this historic, revolutionary mission depends on distinct, socio-political, super-structural factors.)

Marx's writings themselves are ambiguous on the relationship of the two sets of forces. Elsewhere (Adler, 1990), I have argued that this ambiguity arises because these writings, even Capital, mixed the analysis of long-term and shorter-term trends, and combined objective analysis with polemical advocacy. Since around the time of the First World War, the more radical parts of the left have argued that the paleo view concedes too much continuing legitimacy to capitalism. The objection would appear to be that if capitalism continued to foster the development of the forces of production and the working class's capabilities, it would be difficulty to justify radical hostility to it. But in the paleo view, there are plenty of fundamental, and increasingly compelling, reasons for our hostility. Even if the aggregate, long-term trend is towards skill upgrading, the unevenness of this process is a scandal that is increasingly resented. More generally, the Left's hostility is motivated by capitalism's 'savage inequalities' (in J. Kozol's (1991) phrase), its persistent un- and under-employment, its recurrent economic crises and wars, and its ecological irresponsibility. The paleo view allows the Left to advance this critique while acknowledging the progressive aspects of capitalist development. The neo view makes the critique sound like shrill polemic.

We need a good theory of skill. A paleo-Marxist version of labour process theory is a promising starting-point. It allows us to characterize both the fundamental limitations of capitalism and how these limitations conflict with the long-term upgrading trend of skills. In the short term, prospects for radical change due to this escalating conflict may seem dim, but the socialisation thesis puts history on the side of radical social change. 


\section{References}

Abramowitz, M. and P.A. David (1996) 'Technological change and the rise of intangible investments: The US economy's growth part in the Twentieth century,' in OECD (ed.) Employment and Growth in the Knowledge-Based Economy, Paris: OECD.

Adler, P.S. (2003) 'Practice and Process: The socialisation of software development', unpublished manuscript, University of Southern California.

Adler, P.S., (1993) 'The Learning Bureaucracy: New United Motors Manufacturing, Inc.' in B.M. Staw and L.L. Cummings (eds.) Research in Organizational Behavior, vol. 15, Greenwich, CT: JAI Press.

Adler, P.S., (1990) 'Marx, Machines and Skill', Technology and Culture, 31:4, 780-812.

Adler, P.S., Goldoftas, B. and Levine, D. (1997) 'Ergonomics, Employee Involvement, and the Toyota Production System: A Case Study of NUMMI's 1993 Model Introduction', Industrial and Labor Relations Review, 50:3: 416-37.

Adler, P.S., Goldoftas, B. and Levine, D. (1998) 'Stability and change at NUMMI' in R. Boyer, E. Charron, U. Jürgens and S. Tolliday (eds.) Between Imitation and Innovation: The Transfer and Hybridisation of Productive Models in the International Automobile Industry, New York: Oxford University Press.

Babson, S. (ed.) (1995) Lean Work: Empowerment and Exploitation in the Global Auto Industry, Detroit: Wayne State University Press.

Beirne, M., Ramsay, H. and Panteli, A. (1998) 'Developments in computing work: Control and contradiction in the software labour process' in P. Thompson and C. Warhurst (eds.) Workplaces of the Future, Houndmills: Macmillan.

Bell, D. (1973) The Coming of Post-Industrial Society, New York: Basic Books.

Braverman, H. (1974) Labor and Monopoly Capital, New York: Monthly Review Press.

Clark, B. (1999) 'Effects of process maturity on development effort', unpublished paper, http://sunset.usc.edu/ bkclark/Research.

Cohen, G.A. (1978) Karl Marx's Theory of History: A Defense, Princeton: Princeton University Press.

Crosby, P.B. (1979) Quality is Free, New York: McGraw-Hill.

De Geer, H. (1982) Job Studies and Industrial Relations: Ideas about efficiency and relations between the parties of the labour market in Sweden, 1920-1950, Stockholm: Almqvist \& Wiksell International.

DeMarco, T. and Lister, T. (1987) Peopleware: Productive Projects and Teams, New York: Dorset.

Elias, N. (2000) The Civilising Process, Malden, MA: Blackwell.

Engels, F. (1959) 'Socialism: Utopian and Scientific' in L.S. Feuer (ed.) Basic Writings on Politics and Philosophy, Karl Marx and Friedrich Engels, Garden City, NY: Anchor Books.

Engeström, Y. (1987) Learning by Expanding: An Activity-theoretical Approach to Developmental Research, Helsinki: Orienta-Konsultit. 
Engeström, Y. (1990) Learning, Working and Imagining: Twelve Studies in Activity Theory, Helsinki: Orienta-Konsultit.

Fraser, S. (1991) Labor Will Rule: Sidney Hillman and the Rise of American Labor, New York: Free Press.

Friedman, A.L. and Cornford, D.S. (1989) Computer Systems Development: History, Organisation and Implementation, Chichester: John Wiley \& Sons.

Gallie, D. (1994) 'Patterns of skill change: upskilling, deskilling or polarisation?' in R. Penn, M. Rose and J. Rubery (eds.) Skill and Occupational Change, Oxford: Oxford University Press.

Goldin, C. and Katz, L.F. (1999) 'The returns to skill in the United States across the Twentieth century,' National Bureau of Economic Research Working Paper $7126,$.

Greenbaum, J.M. (1979) In the Name of Efficiency, Philadelphia: Temple University Press.

Greenbaum, J.M. (1998) 'The times they are a'changing: Dividing and recombining labour through computer systems' in P. Thompson and C. Warhurst (eds.) Workplaces of the Future, Houndmills: Macmillan.

Grugulis, I., Willmott, H. and Knights, D. (2001) International Studies of Management and Organzsation, Special issue on the Labor Process Debate, 30:4.

Harter, D.E., M.S. Krishnan, S.A. Slaughter, 2000, "Effects of process maturity on quality, cycle time, and effort in software development," Management Science, 46, 4: 451466Herbsleb, J., Zubrow, D., Goldenson, D., Hayes, W. and Paulk, M. (1997) 'Software quality and the Capability Maturity Model' Communication of the ACM, 40:6, 30-40.

Hirschhorn, L. (1984) Beyond Mechanization. Cambridge, MA: MIT Press.

Humphrey, W.S. (2002) 'Three process perspectives: Organizations, Teams, and People', Annals of Software Engineering, 14, 39-72.

Kenney, M., and R. Florida (1993) Beyond Mass Production: The Japanese System and its Transfer to the U.S., New York: Oxford University Press.

Kern, M., and Schumann, M. (1984) Das Ende der Arbeitesteilung?, Munich: C.H. Beck.

Kozol, J. (1991) Savage Inequalities: Children in America's schools, New York: Crown.

Kraft, P. (1977) Programmers and Managers: The Routinisation of Computer Programming in the United States, New York: Springer Verlag.

Krishnan, M.S., Kriebel, C.H., Kekre, S. and Mukhopadhyay, T. (2000) 'Productivity and quality in software products', Management Science, 46:6, 745-59.

Littler, C. (1982) The Development of the Labour Process in Capitalist Societies, London: Heinemann.

Marx, K. (1973) Grundrisse, Harmondsworth: Penguin Books.

Marx, K. (1975) Karl Marx: Early Writings, New York: Vintage.

Marx, K. (1884) The Poverty of Philosophy, Chicago: Charles Kerr \& Company.

Marx, K. and Engels, F. (1959) 'The Communist Manifesto' in L. S. Feuer (ed.) Marx and Engels: Basic Writings on Politics and Philosophy, New York: Anchor. 
Marx. K. (1977) Capital, Vol.1, New York: Vintage.

Mathews, J.A. (1994) Catching the Wave: Workplace Reform in Australia, Ithaca, N.Y.: ILR Press.

Noon, M. and Blyton, P. (2002) The Realities of Work, Basingstoke: Palgrave.

Nyland, C. (1998) 'Taylorism and the Mutual Gains Strategy', Industrial Relations, 37:4: 519-42.

Penn, R. (1984) Skilled Workers in the Class Structure, Cambridge: Cambridge University Press.

Piore, M.J. and Sabel, C.J. (1984) The Second Industrial Divide, New York: Basic Books.

Reich, R. (1993) The Work of Nations, London: Simon \& Shuster.

Schachter, H.L. (1989) Frederick Taylor and the Public Administration Community, Albany NY: State University of New York Press.

Smith, C. and Thompson, P. (1999) 'Reevaluating the Labor Process Debate' in M. Wardell, T.L. Steiger, P. Meiskins (eds.) Rethinking the Labor Process, Albany: State University of New York Press.

Software Engineering Institute (2002) 'Process Maturity Profile of the Software Community, 2002 Mid-year Update', http://www.sei.cmu.edu.

Sohn-Rethel, A. (1978) Intellectual and Manual Labor. Atlantic Highlands, N.J.: Humanities Press.

Spenner, K.I. (1988) 'Technological change, skill requirements, and Education: The case for uncertainty' in R.M. Cyert and D.C. Mowery (eds.) The Impact of Technological Change on Employment and Economic Growth, Cambridge MA: Ballinger.

Standish Group (1994) 'Chaos study report', www.standishgroup.com.

Thompson, P. (1989) The Nature of Work, London: Macmillan.

Turner, H.A. (1962) Trade Union Growth, Structure and Policy, London: George Allen and Unwin.

US Bureau of the Census (1975) Historical Statistics of the United States, Washington DC: US Government Printing Office.

US Bureau of the Census (2000) Statistical Abstract of the United States, Texas: Hoover's Business Press

Van der Pijl, K. (1998) Transnational Classes and International Relations, London: Routledge.

Wardell, M, Steiger, T.L., and Meiskins, P. (eds.) (1999) Rethinking the Labor Process, Albany: State University of New York Press.

Warhurst, C. and Nickson, D. (2001) Looking Good, Sounding Right, London: Industrial Society.

Warren, B. (1980) Imperialism: Pioneer of Capitalism, London: Verso. 